khoảng cách trung bình là 4,56 $1,10 \mathrm{~mm}$.

Mặc dù nghiên cứu này của chúng tôi tập trung vào giải phẫu học của xương mũi, nhưng từ đây có thể có một số ứng dụng về mặt lâm sàng. Ta có thể thấy những nhà phẫu thuật thẩm mỹ khi lên kế hoạch phẫu thuậtthường có xu hướng không phân biệt các chỉ số về kích thước nhân trắc trên da và trên xương. Viêc nhầm lẫn này có thể sẽ dẫn đến những can thiệp thiếu chính xác và mang lại những kết quả không mong muốn. Ngoài ra, việc tìm thây mối tương quan giữa các chỉ số này giúp cho nhà phẫu thuật khi can thiệp cần chú ý đến sự hài hòa giữa các cấu trúc của xương mũi.

\section{KẾT LUÂN}

Các nhà phẫu thuật thẩm mỹ mũi khi phẫu thuật cần cân nhắc đến mối tương quan giữa các kích thước xương mũi, nhằm tạo được một chiếc mũi cân đối, tự nhiên, giảm thiểu biến chứng phẫu thuật và nâng cao sự hài lòng của bệnh nhân.

Bên cạnh đó, cần có những nghiên cứu với cõ mẫu lớn và ứng dụng các kỹ thuật đo tiên tiến đối với các chỉ số không thể đo trực tiếp để làm phong phú thêm nguồn tài liệu tham khảo cho khoa học nhận dạng và pháp y.

TÀI LIỆU THAM KHẢO

1. Han K.H (1998) Rhinoplasty in Aesthetic Plastic Surgery, Koonja Publishing Inc,Seoul, Korea, p. 159.

2. Hwang T.S, Song J, Yoona $H$, et al (2005) "Morphometry of the nasal bones and piriform apertures in Koreans". Annals of Anatomy, 187, pp. 411-414.

3. Lee S.E., Yang T.Y, Han G.S, et al (2008) "Analysis of the nasal bone and nasal pyramid by three- dimensional computed tomography". Eur. Arch. Otorhinolaryngol, 265, pp. 421-424.

4. Trân Thị Anh Tú (2003) Hình thái, cấu trúc tháp mũi người trưởng thành, Luận án tiến sỹ y học, Đại học Y Dược TP Hồ Chí Minh, tr. 30-60.

5. Lang J, Baumeister R (1982) "Uber das postnatale Wachstum der Nasenhohle.". Gegenbaurs Morphol Jahrb, 128, pp. 354-393.

6. Richard Y.Ha, Ricardo A.M (2007) "Rhinoplasty". Selected Readings in Plastic Surgery, 10 (18), pp. 2-3.

7. Lazovic G.D, Daniel R.K, Janosevic L.B, et al (2015) "Rhinoplasty: The Nasal Bones - Anatomy and Analysis". Aesthetic Surgery Journal, 35 (3), pp. 255-263.

8. Palhazi P, Daniel R.K, Kosins A.M (2015) "The Osseocartilaginous Vault of the Nose: Anatomy and Surgical Observations". Aesthetic Surgery Journal, 35 (3), pp. 242-251.

\title{
THỰC TRANG TIÊU VIÊM CHÂN RĂNG HÀM SŨ̃A Ở BÊNHH NHÂN 5-8 TUỔI ĐẾN KHÁM TẠI VIÊ̂N ĐÀO TẠO RĂNG HÀM MĂT VÀ BÊ̂NH VIỆN RĂNG HÀM MẶT TRUNG ƯƠNG HÀ NộI NĂM 2020-2021
}

\author{
Lê Thanh Thúy ${ }^{1}$, Võ Thị Thúy Hồng ${ }^{1}$, Võ Trương Như Ngọc ${ }^{2}$
}

\section{TÓM TĂT}

Tiêu viêm chân răng sữa là một hiện tượng thường gặp trong thực hành lâm sàng của các bác sĩ răng trẻ em và có thế gây những hậu quả đáng tiếc nếu không được phát hiện, điều trị kịp thời. Nghiên cứu nhằm mục đích mô tả tỉ lệ tiêu viềm chân răng ở 1282 răng hàm sữa trên 170 trẻ từ 5 đến 8 tuổi đến khám tại Viênn đào tạo Răng Hàm Mặt và Bệnh viện Răng Hàm Mặt Trung Ương Hà Nội năm 2020-2021. Tình trạng tiều viêm chân răng hàm sữa được đánh giá thổng qua hỏi bệnh, khám lâm sàng và khảo sát trên phim panorama. Kết quả nghiên cứu cho thấy tỉ lệ tiêu viêm chân răng hàm sữa là $23,63 \%$, trong đó tỉ lệ này ở các nhóm răng sâu có tổn thương tủy răng, các răng điều trị tủy kém không làm chup, các răng trám thất bại lần lượt là 56,77\%; 23,1\%; 10,23\%. Kết luận:

${ }^{1}$ Bệnh viện Răng Hàm Mặt TƯHà Nội,

2Trường Đai hoc Y Hà Nội

Chịu trách nhiệm chính: Võ Trương Như Ngọc

Email: votruong nhu ngoc@gmail.com

Ngày nhâan bail 13/4/2021

Ngày phản biên khoa hoc: 6/5/2021

Ngày duyệt bài: 20/5/2021 nhóm các răng sâu có tổn thương tủy răng trong nghiên cứu có tỉ lệ tiêu viêm chân răng cao nhất trong khi nhóm các răng đã điều trị tủy tốt được làm chụp và nhóm răng trám thành công không thấy có hiện tượng tiêu viêm chân răng.

Tư khóa: tiêu chân răng, Viện đào tạo Răng Hàm Mặt, Bệnh viện Răng Hàm Mặt Trung ương Hà Nội.

\section{SUMMARY \\ THE REALITY OF INFLAMMATORY ROOT \\ RESORPTION IN PRIMARY MOLAR IN \\ PATIENTS 5 TO 8 YEARS OF AGE \\ EXAMINED AT SCHOOL OF ODONTO \\ STOMATOLOGY AND HANOI CENTRAL \\ NATIONAL HOSPITAL 2020-2021}

Inflammatory root resorption in primary teeth is a frequent finding in the clinical practice of pediatric dentists and can cause unfortunate consequences without being detected and treated promptly. This study aimed at describing the rate of inflammatory root resorption in 1282 primary molars of 170 children 5 to 8 years of age examined at School of Odonto Stomatology and Hanoi Central National Hospital. The status of inflammatory root resorption in primary 
molars was assessed through questioning, clinical examination and panorama film survey. The results showed that the rate of inflammatory tooth resorption in primary molars was $23.63 \%$, in which this rate in the group of caries with pulp involvement, poor pulpectomy without restoration, the teeth with failed filling is $56.77 \% ; 23.1 \%$; $10.23 \%$, respectively. Conclusion: the group of caries with pulp involvement had the highest rate of inflammatory root resorption while the group of good pulpectomy with restoration and the group of teeth with successful filling did not see inflammatory root resorption.

Keywords: Root resorption, School of Odonto Stomatology, Hanoi Central National Hospital.

\section{I. ĐẶT VẤN ĐỀ}

Tiêu viêm chân răng sữa là một hiện tượng khá phổ biến trong thực hành lâm sàng của các bác sĩ răng trẻ em. ${ }^{1,2}$ Trên phim $x$-quang, hiện tượng này được đặc trưng bởi sự mất cấu trúc của răng và xương ổ răng vùng kế cận với hình ảnh thấu quang liên tục. ${ }^{3}$

Sự tiêu viêm chân răng sữa thường được chẩn đoán bằng cách khám trên lâm sàng và khảo sát trên phim $x$-quang. Trong đó phim panorama là một công cụ phổ biến được sử dụng trong răng trẻ em. Trên phim chúng ta có thể quan sát được toàn cảnh bộ răng của trẻ, mối tương quan giữa chân răng sữa và các tổ chức xung quanh. Thêm vào đó, phim khá thuận tiện khi sử dụng cả ở những bệnh nhân há miệng nhỏ. ${ }^{4}$

Mặc dù có nhiều nghiên cứu trong các tài liệu báo cáo về thực trạng và các yếu tố liên quan đến sự phát triển của sự tiêu chân răng ở răng vĩnh viễn nhưng có rất ít những nghiên cứu nói về sự tiêu chân răng bệnh lý ở răng sữa. ${ }^{1}$ Hơn nữa, loại hình tiêu chân răng sữa này gặp rất thường xuyên trong thực hành lâm sàng của bác sĩ răng trẻ em và hiện tượng sâu răng hàm sữa ở trẻ khá phổ biến, thường gây biến chứng tủy răng dẫn đến tiêu chân răng bệnh lý. ${ }^{4}$ Nếu không được phát hiện kịp thời thì nó có thể dẫn tới hậu quả đáng tiếc như mất răng sữa sớm, đặc biệt vùng răng hàm sẽ ảnh hưởng tới chức nằng ắn nhai của trẻ, các răng kế cận có nguy cơ xô lệch vào khoảng mất răng và răng vĩnh viễn tương ứng mọc lên thay thế có thể mọc lệch hướng. Do đó, nghiên cứu về hiện tượng này có tầm quan trọng đáng kể để chẩn đoán và lập kế hoạch chăm sóc răng miệng cho trẻ.

Trên thế giới đã có nghiên cứu của VieiraAndrade RG và cộng sự năm 2012 tại Brazil cho thây tình trạng tiêu viêm chân răng hàm sữa xuất hiện khá phổ biến với tỉ lệ là $16,2 \%$ và tỉ lệ này cao hơn ở các răng sâu có tổn thương tủy răng, ở các răngđã điêu trị tủy và lấy tủy buồng.
Ở Việt Nam hiện chưa có nghiên cứu nào về tỉ lệ tiêu viêm ở chân răng sữa cũng như nghiên cứu về các yếu tố liên quan ảnh hưởng tới tình trang này. Xuất phát từ thực tiễn đó, chúng tôi tiển hành nghiên cứu: "Thực trạng tiêu viêm chân răng hàm sữa ở bệnh nhân $5-8$ tuổi đến khám tại Viện đào tạo Răng Hàm Mặt và Bệnh viện Răng Hàm Mặt Trung ương Hà Nội năm 2020-2021"với muc tiêu: Mô tả tỉ lệ tiêu viêm chân răng hàm sữa ở bệnh nhân 5 - 8 tuổi đến khám tại Viện Đào tạo Răng Hàm Mặt và Bệnh viện Rắng Hàm Mặt Trung Ương Hà Nội năm 2020 - 2021.

\section{II. ĐỐI TƯợNG VÀ PHƯƠNG PHÁP NGHIÊN CỨU 2.1. Đối tượng \\ Tiêu chuẩn lựa chọn: Bệnh nhân trẻ em từ} 5 đến 8 tuổi đến khám tại Viện Đào tạo Răng Hàm Mặt và Bệnh viện Răng Hàm Mặt Trung Ương Hà Nội thỏa mãn: còn ít nhất 4 rằng hàm sữa, có chì định chụp phim panorama, phim panorama của bệnh nhân chụp đạt tiêu chuẩn, không có tiền sử chấn thương vùng răng hàm

Tiêu chuẩn loại trừ: Không mắc các bệnh toàn thân và các bệnh như cường tuyến cận giáp, hạ canxi máu, bệnh Paget,...

\subsection{Phương pháp nghiên cứu:}

Thiết kế nghiên cứu: nghiên cứu mô tả cắt ngang

Cỡ mẫu nghiên cứu: Áp dụng công thức tính cõ mẫu cho việc xác định một tỉ lệ trong cộng đồng trong nghiên cứu mô tả cắt ngang. ${ }^{5}$

$$
\mathrm{N}=\mathrm{Z}_{(1-\alpha / 2)}^{2} \frac{\mathrm{p} \cdot(1-\mathrm{p})}{\Delta^{2}}
$$

Trong đó: - N là cõ mẫu tối thiểu

- p là ước đoán tỉ lệ tiêu chân răng sữa do viêm (lấy theo nghiên cứu của Raquel Goncalves Vieira- Andrade và cộng sự ở trường Đại học Rio Verde Valley- Unico, Brazil, $p=0,162){ }^{1}$

- a là mức ý nghĩa thống kê, chọn $a=0,05$ thiz $=1,96$.

$\Delta$ là sai số ngẫu nhiên của ước lượng (là sự khác biệt giữa tỉ lệ $p$ thu được trên mấu và tỉ lệ $p$ thật trong quần thể), chọn $\Delta=0,04$.

Áp dụng công thức trên tính ra cỡ mẫu tối thiểu là 326 răng. Thực tế đã thu thập số liệu được 1282 răng trên 170 bệnh nhân.

Chọn mẫu: Chọn mẫu thuận tiện, lựa chọn bệnh nhân trẻ em từ 5 đến 8 tuổi đến khám tại viện đào tạo Răng Hàm Mặt-trường Đại học $Y$ Hà Nổi và Bệnh viện Răng Hàm Mặt trung ương Hà Nội thoả mãn tiêu chuẩn lựa chọn và không có yếu tố nào thuộc tiêu chuẩn loại trừ cho đến khi đủ cõ mẫu nghiên cứu. 


\section{Biến sốnghiên cứu:}

+ Các biến số về đặc trưng của nhóm đối tượng nghiên cứu: tuổi, giới, bệnh toàn thân

+ Các biến số về tình trạng răng: tiêu sinh lý, tiêu viêm, sâu răng có tổn thương tủy răng, sâu răng không tổn thương tủy răng, răng đã được điều trị tủy buồng, răng đã được điều trị tủy toàn bộ, răng đã được trám, răng đã được phục hồi bằng chụp

\section{Quy trinh tiến hành nghiên cứu}

Bước 1: Những đối tượng thỏa mãn tiêu chuẩn lựa chọn được xác nhận sự tự nguyện đồng ý tham gia của phụ huynh trẻ bằng vằn bản. Thu thập thông tin hành chính; Bước 2: Hỏi bệnh, khám bệnh nhân và khảo sát trên phim panorama và hoàn thành bệnh án nghiên cứu; Bước 3: Nhập và xử lý số liệu; Bước 4: Tổng hợp số liệu và viết báo cáo.

2.3. Xử lí số liệu. Tất cả các bệnh án nghiên cứu và phim $x$-quang sau khi kiểm tra, các số liệu sẽ được mã hóa và nhập, xử lý bằng phần mềm thống kê SPSS 20.

2.4. Đạo đức nghiên cứu. Đây là nghiên cứu quan sát, do đó nguy cơ đối với đối tượng nghiên cứu là tối thiểu hoặc gần như không có. Khách quan trong đánh giá, phân loại, trung thực trong xử lý số liệu. Đảm bảo quyền riêng tư của đối tượng nghiên cứu, thông tin thu thập chỉ phục vụ mục đích nghiên cứu và giúp cho công tác dự phòng, điều trị đạt kết quả tốt hơn.

\section{KẾT QUẢ NGHIÊN CỨU}

3.1. Đặc điểm của đối tượng nghiên cứu

Nghiên cứu được thực hiện trên 1282 răng hàm sữa ở 170 bệnh nhân ( tuổi trung bình: $6,5 \pm 1,5)$, trong đó có $64,71 \%$ là nam $(\mathrm{n}=110)$ và $35,26 \%$ là nữ $(n=60)$.

Bảng 1. Đặc điểm của đôi tượng nghiên cứu

\begin{tabular}{|c|c|c|c|}
\hline & Iiếm & Tân số (n) & Tí lệ (\%) \\
\hline & 5 & 37 & 21,76 \\
\hline & 6 & 41 & 24,13 \\
\hline Tuổi & 7 & 54 & 31,76 \\
\hline & 8 & 38 & 22,35 \\
\hline & Tống & 170 & 100 \\
\hline & Nam & 110 & 64,71 \\
\hline Giới & Nữ & 60 & 35,26 \\
\hline & Tống & 170 & 100 \\
\hline & Không & 132 & 77,65 \\
\hline Knam & Có & 38 & 22,35 \\
\hline & Tống & 170 & 100 \\
\hline
\end{tabular}

Nhóm trẻ 7 tuối có tỉ lệ tham gia nghiên cứu cao nhất chiếm $31,76 \%$. Tỉ lệ nam giới tham gia vào nghiên cứu là $64,71 \%$, cao hơn so với nữ giới chiếm 35,26\%.Tỉ lệ các đối tương tham gia nghiên cứu đi khám răng miệng định kì là $22,35 \%$ thấp hơn nhóm không đi khám định kì là 77,65\%.

\subsection{Thực trang tiêu viêm chân răng hàm sữa}

\section{Bảng 2. Ti lệ̉ tiếu viêm chân răng hàm sữa}

\begin{tabular}{|c|c|c|c|c|}
\hline \multicolumn{2}{|c|}{ Tình trạng răng } & $\begin{array}{c}\text { Số lượng răng } \\
\text { nghiên cứu }\end{array}$ & $\begin{array}{c}\text { Số lượng răng } \\
\text { tiêu viêm }\end{array}$ & $\begin{array}{c}\text { Tỉ lệ \% răng } \\
\text { tiếu viêm }\end{array}$ \\
\hline \multicolumn{2}{|c|}{ Răng khỏe mạnh } & 392 & 2 & 0,66 \\
\hline \multirow[t]{2}{*}{ Răng sâu } & Không tốn thương tủy & 375 & 4 & 1,32 \\
\hline & Có tốn thương tủy & 186 & 172 & 56,77 \\
\hline \multirow{2}{*}{ Răng trám } & Thành công & 54 & 0 & 0 \\
\hline & Thất bại & 139 & 31 & 10,23 \\
\hline \multicolumn{2}{|c|}{ Răng đã làm chụp thép } & 4 & 1 & 0,33 \\
\hline \multirow{2}{*}{$\begin{array}{l}\text { Răng điều } \\
\text { trị tủy tốt }\end{array}$} & Có làm chụp & 17 & 0 & 0 \\
\hline & Không làm chụp & 7 & 1 & 0,33 \\
\hline \multicolumn{2}{|c|}{ Răng đã lấy tủy buồng } & 20 & 14 & 4,62 \\
\hline \multirow{3}{*}{$\begin{array}{l}\text { Răng điêuu trị tủy } \\
\text { kém }\end{array}$} & Có làm chụp & 8 & 8 & 2,64 \\
\hline & Không làm chụp & 80 & 70 & 23,1 \\
\hline & Tống & 1282 & 303 & 23,63 \\
\hline
\end{tabular}

Tỉ lệ tiêu viêm chân răng hàm sữa là $23,63 \%$ $(n=303$ răng), trong đó các răng sâu có tổn thương tủy răng, các răng đã trám thất bại và răng điêu trị tủy kém không làm chụp có tỉ lệ tiêu viêm chân răng cao với tî lệ lần lượt là $56,77 \% ; 10,23 \% ; 23,1 \%$.

\section{BÀN LUẬN}

Nghiên cứu có sự tham gia của các trẻ 7 tuổi là nhiêu nhất chiếm 31,76\%. Các nhóm 5 tuổi, 6 tuổi và 8 tuổi lần lượt chiếm tỉ lệ là $21,76 \%$; $24,13 \%$ và $22,35 \%$. Nhóm trẻ 7 tuổi có tỉ lệ tham gia nghiên cứu nhiều nhất có thể là do ở độ tuối này trẻ bắt đầu mọc các răng cửa trên là vùng thẩm mỹ nên được bố mẹ quan tâm đưa đi khám răng nhiều hơn.

Số trẻ nam tham gia nghiên cứu nhiều hơn trẻ nữ gấp 1,83 lần. Điều này có thể giải thích có thể do trẻ nam lười chăm sóc răng miệng hơn 
trẻ nữ nên có thể có các vấn đề về răng miệng nhiều hơn hoặc cũng có thể do trẻ nam được quan tâm nhiều hơn trẻ nữ nên được bố mẹ đưa đi khám răng nhiều hơn.

Tỉ lệ trẻ không được đi khám răng định kì trong nghiên cứu là $77,65 \%$ cao hơn gấp 3,47 lần so với số trẻ được đi khám răng định kì là $22,35 \%$. Điều này có thể do bố mẹ trẻ chưa ý thức được tầm quan trọng của việc khám răng định kì, thường trẻ đau mới cho trẻ đi khám răng nên tỉ lệ trẻ được đi khám răng định kì còn khá thấp.

Tỉ lệ tiêu viêm chân răng hàm sữa trong nghiên cứu này là $23,33 \%$. Tỉ lệ này cao hơn so với nghiên cứu của Raquel Goncalves VieiraAndrade và cộng sự ở trường Đại học Rio Verde Valley- Unico năm 2012 tại Brazil (16,2\%). Điều này có thể là do sự chăm sóc răng miệng ở trẻ em Viêt Nam từ 5-8 tuổi còn chưa được tốt, bệnh lý sâu răng chưa được kiểm soát và điều trị triệt để khiến tỉ lệ tiêu viểm chân răng hàm sữa vẫn còn khá cao.

Bảng 2 cho thây tình trạng của các răng tiêu viêm tham gia nghiên cứu theo số lượng và tỉ lệ. Chiếm phần lớn các răng tiêu viêm trong nghiên cứu thuộc nhóm răng sâu có tổn thương tủy với số lượng và tỉ lệ lần lượt là 172 răng $(56,77 \%)$, cao hơn gấp 86 lần so với răng khỏe mạnh và cao hơn gấp 43 lần so vớinhóm răng sâu không có tổn thương tủy răng. Theo nghiên cứu của Raquel Goncalves Vieira- Andrade và cộng sự năm 2012 tại Brazil thì nhóm răng sâu có tổn thương tủy răng cũng có tỉ lệ tiêu viêm chân răng hàm sữa cao hơn gấp 7 lần. Điều này có thể được giải thích do ở những răng sâu có tổn thương tủy răng thì nhiễm trùng ở tủy răng có thể lan ra vùng quanh răng thông qua lỗ chóp hoặc qua các ống ngà, các mô lót bề mặt chân răng như xi măng và lớp tiền ngà có thể bị phá hủy hoăc thay đổi tính chất hóa học. Các ống ngà bị nhiễm khuẩn có thể kích thích quá trình viêm nhờ kích hoạt hoạt động của các hủy cốt bào ở mô quanh răng hoặc bên trong buông tủy do đó khởi phát nội tiêu hoặc ngoại tiêu chân răng. Mặt khác, ở răng hàm sữa, nhiễm trùng tủy răng dễ lan nhanh hơn đến khu vực giữa các chân răng hơn do độ dày của sàn buồng tủy thấp hơn và có sự hiện diện của nhiều ống tủy phụ ở vùng chẽ chân răng. Kết quả là có sự mất xương xảy ra ở khu vực chẽ chân răng, nhiễm trùng lan rộng và gây ra tiêu chân chân răng. Do vậy, các răng sâu có tổn thương tủy răng thường có tỉ lệ tiêu viêm chân răng cao hơn so với các răng sẩu không có tổn thương tủy răng.

Mất răng hàm sữa sớm có thể gây ra một số hậu quả không mong muốn bao gồm gây mất khoảng cho răng vĩnh viễn kế tiếp mọc và sự nghiêng gần của các răng bên cạnh. Điều trị tủy được coi là phương pháp điều trị hợp lý để đảm bảo sự rụng răng bình thường và duy trì sự tồn tại lâu dài của răng cho đến tuổi thay. Mặc dù là một lựa chọn bảo tồn hơn so với nhổ răng nhưng điều trị tủy cũng là một thách thức để có thể bảo tồn được răng vĩnh viễn ở dưới và có thể duy trì sự tiêu chân răng sinh lý. Trong nghiên cứu này, nhóm răng điều trị tủy kém chưa làm chụp cũng có tỉ lệ tiêu viêm chân răng khá cao là $23,1 \%$, cao hơn gấp 8,75 lần so với nhóm răng điêu trị tủy kém có làm chụp. Tỉ lệ này cao có thể do sai sót trong quá trình điều trị tủy ví dụ như chất hàn có thể ra ngoài chân răng hoặc chưa sửa soạn hết chiều dài chân răng khiến vi khuẩn còn tồn đọng trong phần chân răng còn lại tiếp tục gây phá hủy chân răng dẫn đến tình trạng tiêu bệnh lý. Hơn nữa, ở các răng đã điều trị tủy mà không được phục hình bằng chụp thép hoặc chụp sứ thì mối trám ở thân răng rất dễ bị vỡ khiến vi khuẩn bên ngoài có thể tái xâm nhập vào bên trong hệ thống ống tủy gây tiêu chân răng.

Nhóm răng trám thất bại có tỉ lệ tiêu viêm chân răng là 10,23\%, cao thứ 3 trong nghiên cứu này. Tî lệ tiêu viêm ở nhóm này cao có thể được giải thích do mối trám bị bong vỡ, hở rìa khổng đảm bảo chất lượng khiến vi khuẩn vẫn có thể tấn công tủy răng và hậu quả là tiêu viêm chân răng.

Ngày nay, nội nha trẻ em tập trung vào việc bảo tồn tủy răng nhiều nhất có thể cho đến khi tiêu chân răng sinh lý xảy ra để duy trì khoảng cách giữa các răng, duy trì chức năng ăn nhai và tính thẩm mỹ của trẻ. Lấy tủy buồng là thủ thuật phổ biến cho răng sữa sâu to không có triệu chứng vì ở trẻ em rất khó để đánh giá chính xác được tình trạng tủy răng. Trong nghiên cứu này, nhóm răng đã lấy tủy buồng không làm chụp có tỉ lệ tiêu viêm chân răng là 4,62\%, cao hơn gấp 7 lần so với nhóm răng khỏe mạnh. Theo nghiên cứu của Raquel Goncalves Vieira- Andrade và cộng sự năm 2012 tại Brazil thì ở các răng đã lấy tủy buồng cũng có tỉ lệ tiêu viêm chân răng hàm sữa cao hơn gấp 3 lần so với các răng khác. Điều này có thể giải thích có thể là do các sai sót kĩ thuật trong quá trình lấy tủy buồng như thời gian làm thủ thuật kéo dài, không đảm bảm vô khuẩn trong quá trình lấy tủy buồng, vật liệu che tủy không thích hợp hoặc sau khi lấy tủy buồng răng không được phục hồi lại bằng chụp khiến mối trám ở trên bị vỡ, hở rìa khiến vi khuẩn tái xâm nhập vào hệ thống ống tủy và gây tiêu chân răng. 
Nhóm răng trám thành công và nhóm răng đã điều trị tủy tốt đã làm chụp đều không tiêu chân răng do viêm. Điều này chứng tỏ nếu các răng sâu được kiểm soát và điều trị đúng thì sẽ không có hiện tượng tiêu viêm chân răng xảy ra.

\section{KẾT LUẬN}

Tỉ lệ tiêu viêm chân răng hàm sữa ở trẻ 5-8 tuổi đến khám ở Viện Đào tạo Răng Hàm Mặt và Bệnh viện Răng Hàm Mặt Trung Ương Hà Nội là $23,33 \%$. Nhóm các răng sâu có tổn thương tủy răng trong nghiên cứu có tỉ lệ tiêu viêm chân răng cao nhất trong khi nhóm các răng đã điều trị tủy tốt được làm chụp và nhóm răng trám thành công không thấy có hiện tượng tiêu viêm chân răng. Nghiên cứu của chúng tôi mới áp dụng trên nhóm trẻ ở độ tuổi từ 5-8 tuổi, nghiên cứu tiếp theo có thể mở rộng độ tuổi, so sánh giữa các độ tuổi khác nhau đồng thời khảo sát ở các cơ sở khám chữa bệnh khác và xác định các yếu tố liên quan đến tình trạng tiêu viêm chân răng sữa.

Lời cảm ơn. Nhóm nghiên cứu xin bày tỏ lời cảm ơn tới các bệnh nhân, phụ huynh trẻ đã tham gia nghiên cứu và Viện Đào tạo Răng Hàm
Mặt- Trường Đại học Y Hà Nội, Bệnh viện Răng Hàm Mặt Trung Ướng Hà Nội đã hỗ trợ để thực hiện nghiên cứu này.

\section{TÀI LIÊU THAM KHẢO}

1. Vieira-Andrade RG, Drumond $C L$, Alves LPA, Marques LS, Ramos-Jorge ML. Inflammatory root resorption in primary molars: prevalence and associated factors. Brazilian Oral Research. 2012;26(4):335-340. doi:10.1590/S1806 83242012000400009.

2. Santos BZ, Bosco VL, Silva JYB da, Cordeiro MMR. Physiological and pathological factors and mechanisms in the process of root resorption in primary teeth. RSBO (Online). 2010;7(3):332-339.

3. Cardoso M, Rocha MJ de C. Identification of factors associated with pathological root resorption in traumatized primary teeth. Dent Traumatol. 2008;24(3):343-349.doi:10.1111/j.1600-9657. 2007.00554.

4. Mulia DP, Indiarti IS, Budiarjo SB. Effect of root resorption of primary teeth on the development of its permanent successors: An evaluation of panoramic radiographs in 7-8 yearold boys. J Phys: Conf Ser. 2018;1073:032015. doi:10.1088/1742-6596/1073/3/032015.

5. Đoàn Quốc Hưng, Nguyê̂n Đăng Vững và Đỗ Thị Thanh Toàn. Phương Pháp Nghiên Cứu Trong Y Sinh Học. Nhà xuất bản Y học; 2018.

\section{MỐI LIÊN QUAN CỦA CÁC YẾU TỐ NGUY CO' VớI BỆNH VIÊM QUANH RĂNG MẠN TÍNH}

TÓM TẮT

Mục tiêu: Nghiên cứu nhằm xác định mối liên quan của các yếu tố nguy cơ như sự có mặt của một số vi khuẩn đặc hiệu trong túi quanh răng, tình trạng hút thuốc lá, tuổi, giới... với tình trang phá hủy vừng quanh răng trên một nhóm người Việt nam. Đối tượng và phương pháp: Nghiên cứu bênh chứng trên 113 đối tượng tuổi từ 20 đến 65 gồm 75 bệnh nhân $V Q R$ và 38 người có vùng quanh răng khỏe mạnh. Các đối tượng được khám toàn bộ hai hàm, ghi nhân các chỉ số lầm sàng, tình trang hút thuốc lá và lấy mẫu mảng bám dưới lợi. Các mẫu mảng bám được xét nghiệm vi khuẩn gây bệnh bằng phương pháp PĆR và nuôi cấy phân lập. Các chỉ số lấm sàng và kết quả xét nghiệm vi khuẩn được phân tích bằng phần mềm thống kê Y học Epi Info 6.04. Kết quả: Có mối liên hệ chặt chẽ giữa sự có mặt của A.actinomycetemcomitans T.forsythensis, F. Nucleatum, P.intermedia và tình

*Bênh viện Răng Hàm Mặt TU Hà Nội

*Viên Y Dước lầm sàng 108

Chịu trách nhiệm chính: Nguyễn Thị Hồng Minh

Email: lethuhai3009@gmail.com

Ngày nhận bài: 22/3/2021

Ngày phản biên khoa hoc: 3/5/2021

Ngày duyệt bài: 19/5/2021 trạng hút thuốc lá với OR (độ tin cậy 95\%) lân lượt là 7,$50 ; 3,31 ; 2,37$ và 2,17 . Tình trạng hút thuốc lá có mối liên quan chặt chẽ với tình trạng mất bám dính quanh răng lâm sàng và tình trang tích tụ mảng bám răng . Có mối liên quan chặt chẽ giữa độ tuổi trên 35 với bệnh viêm quanh răng ở nhóm đối tượng nghiên cứu với OR (độ tin cậy $95 \%$ ) là 4,28 và $p<0,01$. Kết luân: Các yếu tố nguy cơ như sự có mặt của một số vi khuẩn đặc hiệu trong túi quanh răng, tình trạng hút thuốc lá, tuổi... có liên quan chặt chễ với tình trạng tiến triển của bệnh viêm quanh răng. Những yếu tố này có thể được coi là yếu tố chỉ điểm cho mức độ trầm trong của bệnh VQR và được sử dụng để tiên lượng cho kết quả điều trị bệnh VQR.

Tư khóa: Viêm quanh răng mạn tính, yếu tố nguy cơ

\section{SUMMARY}

\section{THE RELATION BETWEEN RISK FACTORS WITH CHRONIC PERIODONTITIS}

Objectives: to determine the relation between risk factors such as the present of some putative bacteria in sub- gingival plaque, tobacco smoking, age, sex and periodontitis status in one Vietnamese group. Methods: it was case-control study that carried out in 113 subjects with the age of 20 to 75 included 75 periodontitis patients and 38 healthy periodontal status. Based on full mouth examination, 